\title{
EVALUATION ON THE ECO-INNOVATION LEVEL OF THE TOURISM INDUSTRY IN HEILONGJIANG PROVINCE, CHINA: FROM THE PERSPECTIVE OF DYNAMIC EVOLUTION AND SPATIAL DIFFERENCE
}

\author{
ZI TANG ${ }^{1,2}$, LIN LIU $^{1}$, XIAOHONG LI ${ }^{1}$, CHANGBO SHI $^{1}$, NA ZHANG $^{3}$, ZHENGJIE ZHU $^{1} \&$ JUN BI $^{1}$ \\ ${ }^{1}$ School of Tourism and Cuisine, Harbin University of Commerce, Harbin, China. \\ ${ }^{2}$ Postdoctoral Station of Business Administration, Harbin University of Commerce, Harbin, China. \\ ${ }^{3}$ College of Economics and Management, Northeast Agricultural University, China.
}

\begin{abstract}
The eco-innovation level of the tourism industry may solve the dilemma between tourism innovation and ecological protection. It is an effective method for promoting industry upgrade and sustainable development of tourism economy. This paper established an index system based on pressure-stateresponse-PSR model and evaluated the dynamic change and spatial difference of the eco-innovation level of the tourism industry in Heilongjiang Province by using entropy weight method. The results show that tourism eco-innovation level has been increasing year by year with greater population and environmental pressure from 2005 to 2016. There are obvious differences in each region. In Harbin, tourism eco-innovation level is the highest and the pressure is also greater. The following region is Daxinganling which lacks innovation investment. The index values of other regions are lower and the ability of tourism eco-innovation is weaker. The research results offer references for making policy on tourism innovation and ecotourism development in Heilongjiang Province under the background of ecological civilization.
\end{abstract}

Keywords: Dynamic Evolution; Heilongjiang Province; PSR Model; Spatial Difference; Tourism Eco-Innovation.

\section{INTRODUCTION}

The report to the 19th CPC National Congress points out that innovation is the primary source of development [1]. It promotes economic and social development and enhances comprehensive national strength. Nowadays, global environmental problems are becoming worse because of ecological destruction, environmental pollution and climate change. The concept of eco-innovation has become power source of social and economic sustainable development, which adopts new technology and energy to reduce negative impacts to the environment. Fussler and James [2] first proposed the concept of eco-innovation on the basis of the concept of sustainable development. They referred eco-innovation to new product and process which may reduce environmental impact and add appreciation to the customers and enterprises. In 1997, James clearly defined eco-innovation as new product and process which may reduce environmental impact significantly and add appreciation to all the stakeholders on enterprises, society and environmental responsibility. In 2007, the organization of Measuring Eco-innovation (MEI) [3] which was set up by EU defined it as the following. Eco-innovation is organizational activities on production, adoption or development which may effectively reduce the risk of environment, pollution and negative effects of using resource in the entire life cycle. Organization for Economic Co-operation and Development (OECD) [4] defined it as creative and implemented behavior of environmental improvement on new or significantly improved product (service), production process, market methods, organizational structure and institutional arrangement. Kemp [5], Karakaya et al. [6] and Xavier et al. [7] also differentiate and analyze the concept of eco-innovation. In China, Liu [8] pointed out that 
eco-innovation was an ecologicalization course of social production, distribution, circulation, consumption and reproduction. Yan [9] made a systematic research on the concept and highlighted the features of eco-innovation in his book 'Eco-innovation of Economy Sustainable Development'. Generally, eco-innovation refers to the application of new technology, energy and product, ecologicalization realization in the entire life cycle or each link of production process for reducing negative effects to the environment, and appreciation to the enterprises and customers.

Nowadays, excessive, unordered and commercial development of tourism resource has affected ecological environment and climate change. In the background of economic transformation and ecological civilization construction in China, the tourism industry needs to guide the development of green tourism with innovation driven. In December 2016, the State Council of the PRC put forward the following demands in the third and fifth chapters of the 13th Five-Year Tourism Development Plan, respectively: innovation may propel tourism development and green development may promote the value of tourism ecological civilization [10]. Therefore, it is necessary to make a theoretical discussion on how to improve tourism eco-innovation level in order to reduce environmental negative externality of production behavior. And it becomes one of the issues which academic experts need to focus on. According to the above results, this paper defines tourism eco-innovation as the following, tourism eco-innovation refers to general activities designation of developing and utilizing tourism resource with minimum cost of resource and ecological environment, exploring ecological civilization value of the tourism resource and having maximum tourism revenue through proper combination and adjustment of various elements and requirements by tourism behavioral agent.

Currently, scholars have done more research on tourism innovation and ecotourism but less on the fusion of them. Angela et al. [11] pointed out that knowledge exploitation strategy was the key driving force of developing in eco-innovation of cultural tourism industry. Menezes and Cunha [12] indicated that there is a direct relationship between eco-innovation and competitive strategies in global hotel chains. Alonso-Almeida et al. [13] analyzed eco-innovation condition of global 57 tourism enterprises and found that eco-innovation development was limited and mainly focused on product innovation. Garcia-Pozo et al. [14] made the research on eco-innovation and ecological crisis of hotel industry in Spain and drew a conclusion that eco-innovation affected hotel labor productivity actively. Rosario et al. [15] pointed out that culture management was the necessary condition to encourage eco-innovation implement through analyzing the relationship between organizational culture and eco-innovation of 130 hotels in Mexico. Aboelmaged [16] indicated that eco-innovation regulated environment guidance and suppliers' cooperation influenced hotel performance by the interviews of 182 hotel managers in the United Arab Emirates. In China, Zhang et al. [17] published a series of papers on tourism eco-innovation. Liu et al. [18] measured tourism eco-innovation efficiency of 30 provinces in China by the Malmquist index model and revealed spatial and temporal difference features of tourism eco-innovation efficiency in China. Wang and Zang [19] established index system of tourism eco-innovation on the basis of the pressure-state-response (PSR) model and took Shandong Province as a research example. Shao [20] put forward to strengthen ecological environmental protection and innovate tourism industry development. $\mathrm{Li}$ [21] proposed the method of low-carbon tourism eco-innovation based on the theory of industry convergence. Taken together, the literature of tourism eco-innovation is rare and introducing eco-innovation into tourism research is still in its infancy.

Heilongjiang Province is located in northeast China $\left(121^{\circ} 11^{\prime} \mathrm{E}-135^{\circ} 05^{\prime}, 43^{\circ} 26^{\prime} \mathrm{N}-53^{\circ} 33^{\prime}\right)$, with an area of 473,000 sq. km., accounting for $4.9 \%$ of the national land area (Fig. 1). In 


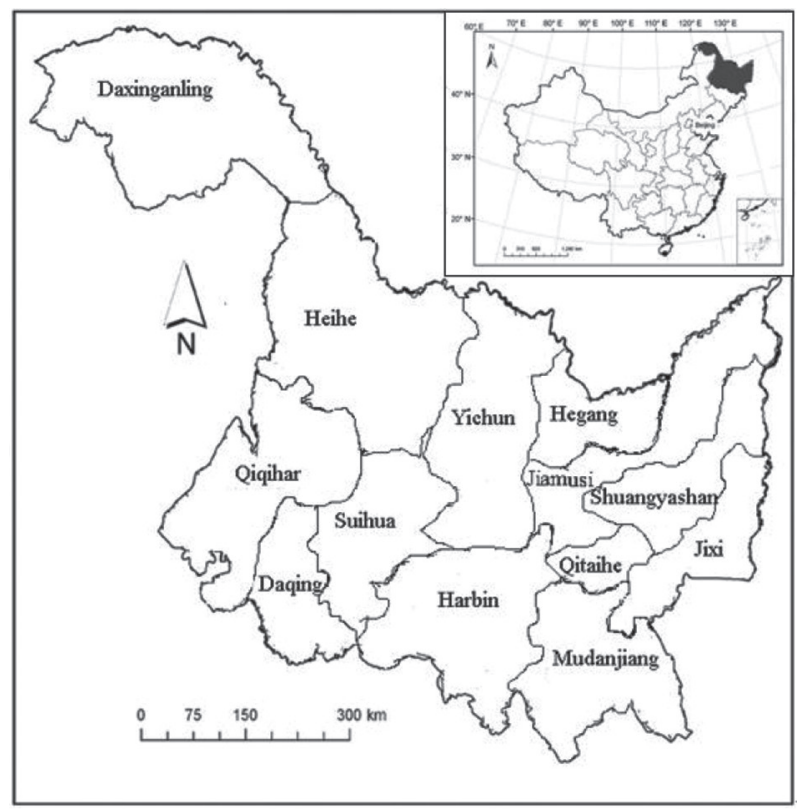

Figure 1: The location of Heilongjiang Province in China.

recent years, tourism development in Heilongjiang Province has formed new situation with distinctive seasonal tourism products for 'northern spring, ecological summer, polychrome autumn mountains and winter ice-snow crown' relying on advantages of ecological environment and resource of lucid waters, lush mountains, ice and snow. The popularity and influence of Heilongjiang Province's tourism are increasing year by year. In 2017, the number of tourists in Heilongjiang Province was 164.081 million and tourism income was 190.9 billion yuan which was equivalent to $11.78 \%$ provincial GDP [22]. The modernization development of the tourism industry in Heilongjiang Province has become an inevitable trend with an extensive use of modern information technology, such as big data, cloud computing and Internet, and so on [23]. Therefore, it is necessary to carry out tourism eco-innovation research in Heilongjiang Province by combining with the construction of ecological civilization and national first-class ecological leisure tourism destination. Based on PSR model, this paper established an index system of tourism eco-innovation level in Heilongjiang Province and determined index weight and comprehensive index according to entropy weight method. Then it got variation trend over time of provincial tourism eco-innovation level and spatial difference features of different regions throughout the province. At last, the corresponding countermeasures were put forward as the references for making policy of tourism innovation and eco-tourism development in Heilongjiang Province under the background of green development.

\section{MATERIALS AND METHODS}

\subsection{PSR model}

PSR model is a generalized ecological evaluation method which is mainly used in environmental research. It is made up of pressure index, state index and response index [24]. 
The analysis of tourism eco-innovation level reflects that tourism activities bring population, environment and resource pressure for the destination while taking advantage of natural and human resources. The pressure may influence economy performance and ecological quality of tourism destination. And then tourism destination responses to them on environment, science and technology, economy and humanity, in order to reduce the damage to ecological environment and promote innovation power of tourism development. Thus the relationship of environment, tourism economy and eco-innovation becomes the pattern of PSR.

\subsection{Establishment of index system}

Based on the theory of PSR model and the experience of related research results [1-19, 25], this study selected the following indicators to form evaluation index system of tourism ecoinnovation level in Heilongjiang Province according to the principles of scientific, comprehensive, systematic, comparable, operable principles and data availability, as shown in Table 1.

PSR model reflects the pressure type of current eco-innovation and the reasons of such a situation from the perspective of PSR. Also, it shows eco-innovation measures which people have taken to improve current ecological situation and enhance local profitability.

'Pressure' index refers to the pressure generated from tourism activities on green system innovation and ecological concept innovation of tourism destinations. 'Tourists' growth rate $\left(P_{1}\right)^{\prime}$ and 'Population density $\left(P_{2}\right)^{\prime}$ are used to evaluate population pressure generated from tourism activities to destinations. 'Volume of waste water discharged $\left(P_{3}\right)^{\prime}$ and 'Emission volume of smoke (powder) dust $\left(P_{4}\right)$ ' are used to evaluate pressure generated from tourism activities to destination environment. 'Energy consumption per unit of GDP $\left(P_{5}\right)$ ' and 'Per capita tourism ecological footprint $\left(P_{6}\right)^{\prime}$ are used to evaluate resource pressure generated from tourism activities to destinations.

'State' index is used to reflect the structure, function condition and dynamic characteristics of entire tourism eco-innovation. Meanwhile, it reflects service function and resources of tourism destinations through economy state, resource state and environment state. Economy state refers to economy performance of tourism eco-innovation, which is evaluated by 'Per capita GDP $\left(S_{1}\right)$ ', 'Tourism economy density $\left(S_{2}\right)$ ' and 'Share of tourism revenue to GDP $\left(S_{3}\right)^{\prime}$. Resource state refers to the dynamic characteristics of tourism eco-innovation, which is mainly evaluated by 'Forest-coverage rate $\left(S_{4}\right)$ ', 'Per capita public green areas $\left(S_{5}\right)$ ', 'Per capita volume of water resources $\left(S_{6}\right)$ ' and 'Coverage rate of nature reserves $\left(S_{7}\right)$ '. Environment state refers to direct performance of tourism eco-innovation on the environment, which is mainly evaluated by 'Daily disposal capacity of city sewage $\left(S_{8}\right)$ '.

'Response' index means guarantee and management ability on reflecting and dealing with the tourism environment problems of destinations, maintaining and improving tourism ecoinnovation. The environment response on improving tourism eco-environment is used to be evaluated by 'Local public financial expenditure in environment protection $\left(R_{1}\right)$ ' and 'Investment in fixed assets in management of water conservancy, environment and public facilities $\left(R_{2}\right)^{\prime}$. The technology response on tourism eco-innovation is used to be evaluated by 'Local public financial expenditure in technology and education $\left(R_{3}\right)$ ' and 'Investment in fixed assets in scientific research and technical service, education and information transmission, software and IT software $\left(R_{4}\right)$ '. The economy response on tourism eco-environment is used to be evaluated by 'Investment in fixed assets in hotels and catering services $\left(R_{5}\right)$ '. The humanity response on tourism eco-innovation is used to be evaluated by 'Number of employment in 
Table 1: Index system of tourism eco-innovation level in Heilongjiang Province.

\begin{tabular}{|c|c|c|c|}
\hline Goal layer & $\begin{array}{l}\text { Criteria } \\
\text { layer }\end{array}$ & $\begin{array}{l}\text { Sub-criteria } \\
\text { layer }\end{array}$ & Element layer \\
\hline \multirow{23}{*}{$\begin{array}{l}\text { Index of } \\
\text { tourism } \\
\text { eco-innovation } \\
\text { level }\end{array}$} & \multirow{6}{*}{$\begin{array}{l}\text { Pressure } \\
(P)\end{array}$} & \multirow{2}{*}{$\begin{array}{l}\text { Population } \\
\text { pressure }\end{array}$} & Tourists' growth rate $\left(P_{1}\right)$ \\
\hline & & & Population density $\left(P_{2}\right)$ \\
\hline & & \multirow{2}{*}{$\begin{array}{l}\text { Environment } \\
\text { pressure }\end{array}$} & Volume of waste water discharged $\left(P_{3}\right)$ \\
\hline & & & Emission volume of smoke (powder) dust $\left(P_{4}\right)$ \\
\hline & & \multirow{2}{*}{$\begin{array}{l}\text { Resource } \\
\text { pressure }\end{array}$} & Energy consumption per unit of $\operatorname{GDP}\left(P_{5}\right)$ \\
\hline & & & Per capita tourism ecological footprint $\left(P_{6}\right)^{1}$ \\
\hline & \multirow{8}{*}{ State $(S)$} & \multirow{3}{*}{$\begin{array}{l}\text { Economy } \\
\text { state }\end{array}$} & Per capita $G D P\left(S_{1}\right)$ \\
\hline & & & Tourism economy density $\left(S_{2}\right)^{2}$ \\
\hline & & & Share of tourism revenue to $\operatorname{GDP}\left(S_{3}\right)$ \\
\hline & & \multirow{4}{*}{$\begin{array}{l}\text { Resource } \\
\text { state }\end{array}$} & Forest-coverage rate $\left(S_{4}\right)$ \\
\hline & & & Per capita public green areas $\left(S_{5}\right)$ \\
\hline & & & Per capita volume of water resources $\left(S_{6}\right)$ \\
\hline & & & Coverage rate of nature reserves $\left(S_{7}\right)^{3}$ \\
\hline & & $\begin{array}{l}\text { Environment } \\
\text { state }\end{array}$ & Daily disposal capacity of city sewage $\left(S_{8}\right)$ \\
\hline & \multirow{9}{*}{$\begin{array}{l}\text { Response } \\
(R)\end{array}$} & \multirow{3}{*}{$\begin{array}{l}\text { Environment } \\
\text { response }\end{array}$} & $\begin{array}{l}\text { Local public financial expenditure in environ- } \\
\text { ment protection }\left(R_{1}\right)\end{array}$ \\
\hline & & & $\begin{array}{l}\text { Investment in fixed assets in management of } \\
\text { water conservancy, environment and public } \\
\text { facilities }\left(R_{2}\right)\end{array}$ \\
\hline & & & $\begin{array}{l}\text { Local public financial expenditure in technol- } \\
\text { ogy and education }\left(R_{3}\right)\end{array}$ \\
\hline & & \multirow[t]{2}{*}{$\begin{array}{l}\text { Technology } \\
\text { response }\end{array}$} & $\begin{array}{l}\text { Investment in fixed assets in scientific research } \\
\text { and technical service, education, information }\end{array}$ \\
\hline & & & transmission, software and IT software $\left(R_{4}\right)$ \\
\hline & & \multirow[t]{2}{*}{$\begin{array}{l}\text { Economy } \\
\text { response }\end{array}$} & $\begin{array}{l}\text { Investment in fixed assets in hotels and cater- } \\
\text { ing services }\left(R_{5}\right)\end{array}$ \\
\hline & & & $\begin{array}{l}\text { Number of employment in management of } \\
\text { water conservancy, environment and public } \\
\text { facilities }\left(R_{6}\right)\end{array}$ \\
\hline & & \multirow[t]{2}{*}{$\begin{array}{l}\text { Humanity } \\
\text { response }\end{array}$} & $\begin{array}{l}\text { Number of employment in scientific research } \\
\text { and technical service, education, information } \\
\text { transmission, software and IT software }\left(R_{7}\right)\end{array}$ \\
\hline & & & $\begin{array}{l}\text { Number of employment in hotels and catering } \\
\text { services }\left(R_{8}\right)\end{array}$ \\
\hline
\end{tabular}

\footnotetext{
${ }^{1}$ Per capita tourism ecological footprint $=($ area of nature reserve + area of parks and green land $) /$ total number of tourists.

${ }^{2}$ Tourism economy density $=$ total number of tourists $/$ GDP.

${ }^{3}$ Coverage of nature reserves $=$ area of nature reserve $/$ total land area.
} 
management of water conservancy, environment and public facilities $\left(R_{6}\right)$ ', 'Number of employment in scientific research and technical service, education and information transmission, software and IT software $\left(R_{7}\right)$ ', 'Number of employment in hotels and catering services $\left(R_{8}\right)^{\prime}$, providing human resources support for ecological technology innovation and ecological concept innovation.

\subsection{Data source and data processing}

In temporal aspect, data of tourism, economy, environment and society in Heilongjiang Province mainly comes from 'Heilongjiang Statistical Yearbook', 'Statistical Bulletin of National Economy and Social Development in Heilongjiang Province', 'China Statistical Yearbook on Environment' and 'China Labour Statistical Yearbook' in the research period from 2005 to 2016. Among them, the data of total tourists number and tourism revenue from 2014 to 2016 cannot be simply compared with the previous data since statistical caliber has changed. This paper readjusted three indices in past three years according to the growth rate in Statistical Bulletin. In spatial aspect, the paper chose the following administrative areas as research objects in view of data availability in 2016: Harbin, Qiqihar, Jixi, Hegang, Daqing, Jiamusi, Mudanjiang, Heihe and Daxinganling. The data sources were the following: '2017 Heilongjiang Statistical Yearbook', Statistical Bulletin of National Economy and Social Development in above regions.

\subsection{Research method}

In order to eliminate the influence of dimension and magnitude, the original data should to be processed by range standardization. $X_{i j}^{\prime}$ is the standardized data by using the following equations [26],

$$
\begin{aligned}
& X_{i j}^{\prime}=\frac{X_{i j}-\min \left\{X_{j}\right\}}{\max \left\{X_{j}\right\}-\min \left\{X_{j}\right\}}\left(\text { when } X_{j} \text { is positive }\right) \\
& X_{i j}^{\prime}=\frac{\max \left\{X_{j}\right\}-X_{i j}}{\max \left\{X_{j}\right\}-\min \left\{X_{j}\right\}}\left(\text { when } X_{j} \text { is negative }\right)
\end{aligned}
$$

where $X_{i j}^{\prime}$ and $X_{i j}$ represent the standardized value and the original value of index $j$ in year $i$, respectively; $\max \left\{X_{j}\right\}$ and $\min \left\{X_{j}\right\}$ are the maximum and minimum value of index $j$ among all years, respectively.

Entropy assigning method is used to calculate the comprehensive level of tourism ecoinnovation [26].

Calculating the proportion of the index $j$ in year $i\left(R_{i j}\right)$,

$$
R_{i j}=X_{i j}^{\prime} / \sum_{i=1}^{m} X_{i j}^{\prime}
$$

Calculating the information entropy of the index $j\left(e_{j}\right)$, and if $X_{i j}^{\prime}=0,0.00001$ is substituted for 0 to calculate $e_{j}$, 


$$
e_{j}=-\frac{1}{\ln m} \sum_{i=1}^{m} R_{i j} \times \ln R_{i j}\left(0 \leq e_{i} \leq 1\right)
$$

Calculating the entropy redundancy $\left(d_{j}\right)$. When $d_{j}$ is higher, $X_{j}$ is more important.

$$
d_{j}=1-e_{j}
$$

Calculating the weight of the index $j\left(\omega_{j}\right)$,

$$
\omega_{j}=d_{j} / \sum_{j=1}^{n} d_{j}
$$

Calculating the comprehensive index in year $i\left(V_{j}\right)$,

$$
V_{j}=\sum_{j=1}^{n} \omega_{j} \times X_{i j}^{\prime}
$$

where the value of $V_{j}$ from 0 to $1 . V_{j}$ is higher, which indicates the greater the level of tourism eco-innovation is. When $V_{j}=1$, the level of tourism eco-innovation is ideal.

\section{RESULTS}

\subsection{Temporal evolution of tourism eco-innovation level}

The pressure index, state index, response index and comprehensive index of tourism ecoinnovation level in Heilongjiang Province can be calculated in accordance with the above index system, selected data and entropy weighting method. The results are shown in Table 2.

Table 2: Tourism eco-innovation level in Heilongjiang Province from 2005 to 2016.

\begin{tabular}{lcccc}
\hline & Pressure index & State index & Response index & Comprehensive index \\
\hline 2005 & 0.552 & 0.035 & 0.016 & 0.177 \\
2006 & 0.548 & 0.075 & 0.083 & 0.214 \\
2007 & 0.559 & 0.099 & 0.123 & 0.240 \\
2008 & 0.531 & 0.237 & 0.153 & 0.291 \\
2009 & 0.508 & 0.368 & 0.356 & 0.404 \\
2010 & 0.461 & 0.480 & 0.458 & 0.466 \\
2011 & 0.264 & 0.544 & 0.518 & 0.454 \\
2012 & 0.203 & 0.610 & 0.611 & 0.493 \\
2013 & 0.205 & 0.743 & 0.716 & 0.578 \\
2014 & 0.194 & 0.724 & 0.739 & 0.577 \\
2015 & 0.421 & 0.856 & 0.817 & 0.716 \\
2016 & 0.558 & 0.929 & 0.823 & 0.783 \\
\hline
\end{tabular}


Pressure index. Pressure index is a converse index. The smaller numerical value refers to the greater pressure and less contribution to tourism eco-innovation. From 2005 to 2014, there was an overall decrease in numerical value of pressure index from 0.552 to 0.194 , which indicated an increase in pressure to ecological system. This was caused by yearly increase in wastewater discharge and smoke (powder) dust emission. On the other hand, tourist growth rate fluctuated greatly in different year and caused the fluctuation of pressure index in individual year. From 2015 to 2016, there was an overall increase in numerical value of pressure index from 0.421 to 0.558 and a decrease in pressure to ecological system. That is mainly because of decrease in wastewater discharge and smoke (powder) dust emission, which made more contribution to tourism eco-innovation in Heilongjiang Province.

State index. From 2005 to 2016, the numerical value of state index increased from 0.035 to 0.929 except in 2014. The results showed that tourism eco-innovation condition was very good in Heilongjiang Province over the years and guaranteed tourism eco-innovation. The following indices have provided the safeguard for the numerical value of state index: per capita GDP, tourism economy density, forest-coverage rate, per capita public green areas, coverage rate of nature reserves, daily disposal capacity of city sewage, and so on.

Response index. As to the temporal change trend, there was an increase trend of numerical value of response index from 0.016 to 0.823 . It showed that tourism eco-innovation in Heilongjiang Province was gradually getting better over the years. The government increased fiscal expenditure and fixed investment on environmental governance, information software, science and technology, education, lodging and catering by accelerating economic transformation. Thus, the employment number of environment, science and technology, education and information industry was larger and tourism eco-innovation environment was greatly improved.

Comprehensive index. There was an overall increase in numerical value of comprehensive index except slight decline in 2011 and 2014. The advantages of state index and response index showed that guarantee and reaction capacity of developing tourism eco-innovation in Heilongjiang Province was better. However, bigger fluctuation of pressure index indicated that environmental carrying capacity of the tourism industry should be concerned.

\subsection{Spatial difference of tourism eco-innovation level}

The administrative areas throughout Heilongjiang Province differ from each other on resources, ecological basis, economy development and science and education information, so does their tourism eco-innovation level. Table 3 shows the differences of tourism eco-innovation level in every administrative area in Heilongjiang Province in 2016.

The ranking of pressure index showed that the following administrative areas such as Daxinganling, Heihe, Mudanjiang and Jiamusi were in the top. Tourism activities bring less pressure to them. The area of forest and wetland in these cities and regions is very large. The ecological system of forest and wetland provide not only a variety of resources for human production and life but also good ecological foundation to local tourism eco-innovation by enormous environmental function and value of ecosystem services. The rank of pressure index shows that Harbin and Daqing were at the bottom with 0.166 and 0.182 , respectively. It indicated that tourism activities brought more pressure to the destinations. The index data showed that the numerical value of index on population pressure, environment pressure and resources pressure of Harbin and Daqing were lower. Tourism eco-innovation index differed slightly the rest administrative areas with the numerical value of index between 0.309 and 0.367 . 
Table 3: Tourism eco-innovation level of various regions in Heilongjiang Province in 2016.

\begin{tabular}{lcccccccc}
\hline & $\begin{array}{c}\text { pressure } \\
\text { index }\end{array}$ & rank & $\begin{array}{c}\text { state } \\
\text { index }\end{array}$ & rank & $\begin{array}{c}\text { response } \\
\text { index }\end{array}$ & rank & $\begin{array}{c}\text { comprehensive } \\
\text { index }\end{array}$ & rank \\
\hline Harbin & 0.166 & 9 & 0.395 & 2 & 1.000 & 1 & 0.703 & 1 \\
Qiqihar & 0.367 & 5 & 0.119 & 9 & 0.132 & 3 & 0.157 & 7 \\
Jixi & 0.333 & 6 & 0.159 & 8 & 0.059 & 6 & 0.124 & 8 \\
Hegang & 0.309 & 7 & 0.205 & 6 & 0.016 & 8 & 0.113 & 9 \\
Daqing & 0.182 & 8 & 0.307 & 3 & 0.118 & 4 & 0.187 & 5 \\
Jiamusi & 0.491 & 4 & 0.184 & 7 & 0.085 & 5 & 0.167 & 6 \\
Mudanjiang & 0.525 & 3 & 0.257 & 4 & 0.138 & 2 & 0.224 & 3 \\
Heihe & 0.735 & 2 & 0.233 & 5 & 0.058 & 7 & 0.198 & 4 \\
Daxinganling & 0.933 & 1 & 0.636 & 1 & 0.004 & 9 & 0.321 & 2 \\
\hline
\end{tabular}

The rank of state index showed that Daxinganling had the highest index, 0.636. It indicated that the condition of tourism eco-innovation in Daxinganling was pretty good because of good ecological environment with higher forest coverage rate, $81.23 \%$. Tourism revenue accounted for $37.78 \%$ of GDP. Harbin ranked second state index, 0.395 . As the capital of Heilongjiang Province, its daily sewage treatment capacity was stronger, reaching 1.4 million cubic meters. It provided environment governance foundation for tourism eco-innovation. Qiqihar had the lowest state index, only 0.119 . The forest coverage rate was low, so was per capita GDP. Qiqihar had the second least per capita GDP in 2016 among nine administrative areas, only 25,690 yuan. In addition, the condition of tourism eco-innovation in Harbin was not good due to more grassland and wetland but less area of forest and lower forest coverage rate. State index in the rest regions were between 0.159 to 0.307 .

The response index of Harbin was 1, ranking the first. It showed stronger tourism ecological innovation ability. The more appropriation expenditure and professional talents on environment, science and education, information technology may provide prominent social and economic supporting ability and stronger tourism scientific innovation ability. The following administrative areas, such as Mudanjiang, Qiqihar, and Daqing, had response indices of $0.138,0.132,0.118$, respectively. They increased cost input and talent cultivation on environmental protection, science and education and information technology to support tourism eco-innovation. Daxinganling ranked the lowest response index, only 0.004 . The ecological environment quality was better in that region so cost input on environment, science, education and information technology was the lowest. It lacked innovative impetus. The response indices of other administrative areas were between 0.016 and 0.085 . The ability of tourism eco-innovation in these regions was a bit weak.

The rank of comprehensive index showed that Harbin had the highest index, 0.703. It had absolute superiority in response index. Ecological innovation ability was stronger, whereas tourism eco-innovation pressure was also greater. So the carrying capability of local tourism development should be considered. The second region was Daxinganling which had comprehensive index of 0.321 . Its pressure index and response index were higher than others. It indicated less pressure of local tourism development and better quality of ecological environment. But it is still necessary to promote the construction of science, education and information 
technology, etc. to provide new development impetus for realizing tourism innovation. Hegang ranked the last because of greater pressure of tourism activities to the destination and serious damage to tourism ecological environment. It is better to take effective measures to offset the weak part of tourism eco-innovation. The comprehensive indices of the rest regions were between 0.124 and 0.224 . The pressure index, state index and response index of these regions were unbalanced and uneven which lead to weak tourism eco-innovation ability.

\section{DISCUSSIONS}

With rapid development of tourism, the environment, ecology, economy, society and culture problems caused by traditional tourism development model are gradually emerging. The concept of sustainable tourism was proposed in 1990. And many experts, institutions and scholars have conducted a lot of researches on time, space, breadth and depth of tourism sustainable development since then. At the same time, the related framework of evaluation index system on tourism sustainable development has also been established and extensive empirical research has been done according to regional reality. Among them, PSR model makes people start thinking the following questions through showing the relationship of 'PSR': How was the change of environment and nature? What were the reasons? What have people done? What should people do? Therefore, it is a dynamic analysis method. It can be used in comprehensive evaluation of tourism destination ecological state, including ecological technology, ecological group, green system, ecological concepts and so on since it is a generalized ecological evaluation index. And it is suitable for evaluation of regional tourism eco-innovation because field research is not necessary for some index [17].

With the popularization of environmental protection concept and vigorous development of tourism industry, eco-civilization awareness of people is gradually awakening. But driven by the growth of tourism demand and tourism benefits, some tourism enterprises or scenic spots may cause environmental pollution if they do not dispose the waste water, waste gas and solid waste timely. And improper development may also cause soil erosion, landscape disharmony and other ecological damage phenomenon [27-29]. In addition, tourists consume water, electricity, coal, petroleum and other natural resources and energy directly or indirectly during their activities of eating and drinking, lodging, traveling, sightseeing, shopping and entertaining. Their activities cause carbon emission which has certain influence on climate change [29-30]. For a long time, tourism operation mode is extensive and ecological protection consciousness of people is lacking in Heilongjiang Province. This wastes resources and energy a lot. So, current tourism development of Heilongjiang Province is widely developed and fast but not competitively strong and superior. Therefore, it is an important task of tourism sustainable development in Heilongjiang province for applying eco-innovation concept to tourism industry and protecting ecological environment with maintained tourism economy growth.

In this paper, the logical thinking of 'cause-effect-response' in PSR model reflects the interaction between tourism eco-innovation, environment and economy. Tourism activities ask for resources from environment and discharge waste to the environment which changes the stock of natural resources and environment quality. And this kind of change affects the quality and economy benefits of tourism activities. Tourism eco-innovation responds to these changes through transformation of product, process and organization and improvement of society and institution in order to reach the purpose of reducing environmental hazards and providing added value. This cycle constitutes the 'PSR' relationship between tourism-innovation, environment and economy [19]. 
Ecological innovation can promote the sustainable development of regional social economy while solving the damage to ecology and environment caused by human activities. The expansion of the tourism economy may bring out the 'ecological deficit'. It is necessary to support the ecological development of the tourism industry in the direction of ecological innovation. This paper introduces the theory of ecological innovation, which provides impetus for the transformation and upgrading and sustainable development of the tourism industry. Tourism eco-innovation is the general term that the behavioral agent need to combine and adjust various elements and conditions, promote the rational development and utilization of tourism resources with minimal resources and ecological environment cost, maximize the value of ecological civilization of tourism resources, and generate the greatest tourist revenue.

Due to the lack of research on tourism eco-innovation, the selection of related indicators and the construction of index systems are still at an exploratory stage. This paper established the index system by referring the literature of some scholars (Zhang J, Wang B). With the abundant of wetlands, forests, lakes, grassland, and other natural resources, Heilongjiang Province has a certain degree of representation as a case. There are 13 administrative areas in Heilongjiang Province. Due to incomplete statistical data of various areas, only nine cities with relatively complete data were selected as the research objects, and four other cities (Shuangyashan, Yichun, Qitaihe and Suihua) were not considered. In addition, considering the consistency of the index system of the whole province and administrative areas, the selected indicators will, to some extent, have an impact on the accuracy of the evaluation conclusions of tourism eco-innovation in Heilongjiang Province. In the future research process, it is necessary to adjust the evaluation index system according to the actual situation, so as to achieve a conclusion that accords with the actual situation.

\section{CONCLUSION}

This paper established an evaluation index system based on PSR model and evaluated tourism eco-innovation level in Heilongjiang Province from the perspective of dynamic evolution and spatial difference. The results showed that there was larger fluctuation of pressure index and an increasing trend of state index, response index and comprehensive index of period 2005 to 2016. That meant tourism eco-innovation level of Heilongjiang Province was increasing year by year. Spatial distribution showed that Harbin has the greatest pressure on tourism eco-innovation. Harbin also has higher state index and response index, so its comprehensive index was the first with high tourism eco-innovation ability. Pressure index and state index of Daxinganling were the first whereas the response index was the last. Therefore, innovative consciousness and tourism eco-innovation level of this region should be improved in the future. The development of Mudanjiang was relatively balanced. However, the numerical value of each index was low with insufficient efforts on environmental management and ecological innovation. The pressure index, state index, response index and comprehensive index of other cities were in the middle of the list. It needs to further strengthened eco- innovation consciousness and action.

Eco-innovation ability will become an important direction of future development of the tourism industry along with the advancement of ecological civilization construction. Based on the above conclusions, this paper proposes the following suggestions. First, the government should guide and promote tourism eco-innovation. Heilongjiang Province governments at all levels should intensify disburse and fixed-asset investment in the field of environmental protection, science, information technology, education and tourism. Building up the supporting system to encourage tourism eco-innovation activities, achievements transformation and experience 
exchange, and so on. Second, every city and region of Heilongjiang Province should enhance tourism eco-innovation level according to local conditions. Some active exchange and cooperation should be carried out among tech enterprises, information enterprises, environmental protection enterprises, universities and research institutions. The efficient and intensive use of ecological resources may reduce the emission of waste water and dust. Ecologization should run through the whole process of exploitation and construction, production and sales, operation and management of the tourism industry. A new model of region linkage and collaborative innovation will be formed with the following five factors, such as tourism economy, science and education information, ecological environment, tech intermediary, and universities or institutes [13].

\section{ACKNOWLEDGMENTS}

This work was supported by the Natural Science Foundation of China (41801137), China Postdoctoral Science Foundation (2016M600257), postdoctoral program of Heilongjiang Province (LBH-Z16093), projects of philosophy and social sciences of Heilongjiang Province (16JYE03, 14E012, 18JYE671, 18JYH765), doctoral and postdoctoral research projects of Harbin University of Commerce (2016BS05, 2017BSH014), and research projects of Harbin University of Commerce (2016QN028, 17XN086), the teaching reform of higher education project of Harbin University of Commerce (HSDJY2018020). The authors are sincerely grateful for the anonymous reviewers' valuable comments and suggestions that have greatly helped to improve the paper's quality.

\section{REFERENCES}

[1] XinhuaNet. Secure a decisive victory in building a moderately prosperous society in all respects and strive for the great success of Socialism with Chinese Characteristics for a new era: delivered at the 19th National Congress of the Communist Party of China. www.xinhuanet.com/politics/19cpcnc/2017-10/27/c_1121867529.htm (accessed 27 October 2017).

[2] Fussler, C. \& James, P., Driving Eco-Innovation: A Break Thorough Discipline for Innovation and Sustainability, London: Pitman Publishing, pp. 1-33, 1996.

[3] Kemp, R. \& Pearson, P., Final report MEI project about measuring eco-innovation. Measuring Eco-innovation Project (MEI), 2007.

[4] OECD. Sustainable manufacturing and eco-innovation: towards a green economy. www.oecd.org/sti/innovation/sustainablemanufacturing OECD, (accessed 16 June 2009).

[5] Kemp, R., Eco-innovation: definition, measurement and open research issues. Economia Politica, 27(3), pp. 397-420, 2010.

[6] Karakaya, E., Hidalgo, A. \& Nuur, C., Diffusion of eco-innovations: A review. Renewable \& Sustainable Energy Reviews, 33(2), pp. 392-399, 2014.

[7] Xavier, A.F., Naveiro, R.M., Aoussat, A. \& Reyes, T., Systematic literature review of eco-innovation models: opportunities and recommendations for future research. Journal of Cleaner Production, 149, pp. 1278-1302, 2017.

[8] Liu, S.H., Theoretical consideration on sustainable economic development. Economic Research Journal, (3), pp. 46-54, 1997. (in Chinese)

[9] Yan, L.D., Ecological Innovation for Sustainable Economic Development, Beijing: China Environmental Science Press, 2002. (in Chinese)

[10] The State Council of PRC. Notice on the development plan of the tourism industry in the 13th five-year plan.www.gov.cn/zhengce/content/2016-12/26/content_5152993.htm (accessed 26 December 2016). 
[11] Martínez-Pérez, A., García-Villaverde, P.M. \& Elche, D., Eco-innovation antecedents in cultural tourism clusters: External relationships and explorative knowledge. Innovation, 17(1), pp. 41-57, 2015.

[12] Menezes, V.O. \& Cunha, S.K., Eco-innovation and competitive strategy in global hotel chains: developing a conceptual relationship model. WIT Transactions on Ecology and the Environment, 201, pp. 177-188, 2016.

[13] Alonso-Almeida, M.D.M., Rocafort, A. \& Borrajo, F., Shedding light on ecoinnovation in tourism: a critical analysis. Sustainability, 8(12), pp. 1262, 2016. https:// doi.org/10.3390/su8121262

[14] García-Pozo, A., Sánchez-Ollero, J.L. \& Ons-Cappa, M., Eco-innovation and economic crisis: a comparative analysis of environmental good practices and labour productivity in the Spanish hotel industry. Journal of Cleaner Production, 138(1), pp. 131-138, 2016.

[15] Rosario, R.S.M.D., Sánchez-Medina, P.S. \& René, D.P., Eco-innovation and organizational culture in the hotel industry. International Journal of Hospitality Management, 65, pp. 71-80, 2017.

[16] Aboelmaged, M., Direct and indirect effects of eco-innovation, environmental orientation and supplier collaboration on hotel performance: an empirical study. Journal of Cleaner Production, 184, pp. 537-549, 2018.

[17] Zhang, J., Yuan, M.H. \& Tang, S.M., Study on tourism ecological innovation theory and innovation scheme: one of the series papers on tourism ecological innovation. Social Sciences in Guangxi, (06), pp. 52-55, 2010. (in Chinese)

[18] Liu, J., Zhao, J.J. \& Yu, Y.X., Measurement of China's tourism eco-innovation efficiency and its influence factors. Reformation \& Strategy, 29(09), pp. 91-96, 2013. (in Chinese)

[19] Wang, B. \& Zang, Y.Z., Innovation evaluation on tourism ecology based on PSR model: take Shandong Province as example. Journal of Shandong University of Science and Technology (Social Sciences), 17(02), pp. 71-78, 84, 2015. (in Chinese)

[20] Shao, Q.W., Strengthen ecological and environmental protection, develop the tourism industry in an innovative way. Science \& Technology Industry of China, (01), pp. 49-50, 2016. (in Chinese)

[21] Li, X.Q., Study on the innovation path of low-carbon tourism industry based on the theory of industry integration. Journal of Southwest Minzu University (Humanities and Social Science), (02), pp. 126-130, 2016. (in Chinese)

[22] Heilong jiang Bureau of Statistics. Statistical bulletin on national economic and social development of Heilongjiang Province in 2017. www.hlj.stats.gov.cn/tjgb/shgb/201804/ t20180411_63136.htm (accessed 11 April 2018).

[23] Tourism Development Committee of Heilongjiang Province. Circular on printing and issuing the "13th five-year plan" for the tourism industry in Heilong jiang Province. www.hljtour.gov.cn/zhy_zwgk_content.jsp?id=14004\&gglb=233 (accessed 28 March 2018).

[24] OECD. Pressure-State-Response Framework and Environmental Indicators, Paris, Organization for Economic Cooperation and Development, 2009.

[25] Chen, J., Cheng, J. \& Dai, S., Regional eco-innovation in China: an analysis of eco-innovation levels and influencing factors. Journal of Cleaner Production, (153), pp. 1-14, 2017.

[26] Tang, Z. An integrated approach to evaluating the coupling coordination between tourism and the environment. Tourism Management, (46), pp. 11-19, 2015.

[27] Taylor, G. \& Stanley, D., Tourism, sustainable development and the environment: an agenda for research. Tourism Management, 13(3), pp. 341-342, 1992. 
[28] Gössling, S., Global environmental consequences of tourism. Global Environmental Change, (12), pp. 283-302, 2002.

[29] Asmelash, A.G. \& Kumar, S., Assessing progress of tourism sustainability: Developing and validating sustainability indicators. Tourism Management, 71, pp. 67-83, 2019.

[30] UNWTO-UNEP-WMO. Climate Change and Tourism: Responding to Global Challenges, World Tourism Organization, Madrid, Spain, 2008. 